\title{
Tindak Tutur dan Nilai Karakter pada Seni Tari Gambuh yang berjudul "Swayamwara" Sesuai dengan 18 Nilai Karakter Kurikulum 2013
}

\author{
Ngurah Agung Riski Restuaji, \\ Denpasar Indonesia \\ gungriskikendang@yahoo.co.id \\ Ni Made Suryati, \\ Universitas Udayana, Indonesia \\ made_suryati@unud.ac.id
}

\begin{abstract}
Abstrak
Penelitian ini bertujuan untuk mengetahui jenis-jenis tindak tutur, fungsi komunikasi, dan nilai karakter yang terkandung pada seni tari gambuh dengan judul "Swayamwara" sesuai dengan nilai karakter yang terkandung pada kurikulum 2013. Sumber data berupa rekaman video pementasan tari gambuh yang selanjutnya ditranskripsi kemudian dianalisis dengan menggunakan teori tindak tutur dan selanjutnya nilai-nilai karakter dianalisis sesuai dengan nilai karakter yang terdapat pada kurikulum 2013.

Hasil penelitian ini menunjukkan bahwa dari penggalan percakapan yang dipilah menjadi 39 data ditemukan 17 data yang mengandung makna lokusi, 20 data dengan makna ilokusi, dan 2 data mengandung makna perlokusi. Pada bentuk dan fungsi komunikasi ditemukan 11 data dengan fungsi komunikasi asertif, 5 data dengan fungsi direktif, 2 data dengan fungsi komisif, 15 data dengan fungsi ekspresif, dan 1 data dengan fungsi deklaratif. Dari 18 nilai karakter yang ada pada kurikulum 2013, ditemukan 12 nilai karakter yang terdapat pada seni tari gambuh meliputi nilai religius, toleransi, disiplin, kerja keras, demokrasi, rasa ingin tahu, semangat kebangsaan, cinta tanah air, menghargai prestasi, bersahabat, peduli sosial, dan nilai tanggung jawab. Pada penelitian ini ditemukan satu nilai yang tidak terdapat pada kurikulum 2013, yakni nilai keberanian.
\end{abstract}

\section{Kata kunci: Tindak tutur, fungsi komunikasi, nilai karakter, tari gambuh}

\section{Abstract}

The research aimed to know about kinds of speech act, communication functions, and character values which were existed in gambuh dance with the title "Swayamwara" according to the character values in the curriculum of 2013. The research applied descriptive qualitative method. The method of collecting data was observation, interview, and scrutinized (listening and seeing method) with the techniques of take notes, tap (sadap), and free scrutinize(simak bebas libat cakap). Data source was a video recording of gambuh dance. It was transcribed and analyzed using speech act theory, then the character values were analyzed using character values in the curriculum of 2013.

The results of this research show that the data in the form of conversations which were divided into 39 parts, consisted of 17 conversations have locution meaning, 20 conversations have illocution meaning, and 2 conversations have perlocution meaning. For communication functions were founded 11 conversations have asertif function, 5 conversations have direktif function, 2 conversations have komisif function, 15 conversations have ekspresif function, and 1 conversation has deklaratif function. From 18 character values founded in the curriculum of 2013, there were 12 character values which were founded in the conversation of gambuh dance such as: religion, tolerance, discipline, hard work, democracy, willing to 
know, national spirit, love country land, achievement respect, friendship, social care, and responsibility. In this research there was one value founded but not existed in the curriculum of 2013, the value of courage.

\section{Keywords: Speech act, communication functions, character values, and gambuh dance}

\section{Latar Belakang}

\section{Pendahuluan}

Pementasan kesenian drama tari memiliki beragam kelebihan dalam penyampaian pesanpesannya apabila dibandingkan dengan bidang lainnya. Hal ini disebabkan oleh pementasan kesenian drama tari bersifat tradisional sehingga tuturan yang digunakan akan lebih mudah untuk dimengerti oleh masyarakat lokal. Pementasan kesenian tersebut disampaikan secara langsung dalam sebuah pementasan sehingga pesan-pesan yang disampaikan dalam pementasan akan memberikan efek langsung bagi penonton yang menonton pementasan tersebut. Selain itu, pementasan kesenian drama tari selalu memberikan tuturan tentang nilai-nilai kebaikan yang disampaikan dalam lakonnya melalui bentuk gerak tari, mimik wajah, dan suara (lagu) sehingga akan sangat menarik untuk ditonton. Di Bali terdapat banyak sekali bentuk pementasan drama tari. Drama tari yang tertua dan terklasik adalah kesenian tari gambuh.

Gambuh adalah sebuah drama tari warisan budaya Bali yang memperoleh pengaruh dari drama tari zaman Hindu di Jawa Timur (Gandarajiwana, 2012:1), Dalam pementasannya, gambuh menggunakan bahasa Kawi untuk tokohtokoh utama dan untuk tokoh lainnya menggunakan bahasa Bali.

Informasi yang diberikan dalam pementasan gambuh tersebut tentu saja bukan hanya tentang nilai-nilai kebaikan politik pada zaman kerajaan, melainkan juga tentang nilai-nilai karakter kebaikan untuk generasi penerus. Hal ini menjadi sangat penting, mengingat di zaman sekarang ini sistem pendidikan di Indonesia juga sangat menekankan adanya penanaman nilai-nilai kebaikan dalam sistem pendidikan karakter.

Pengembangan karakter bangsa dapat dilakukan melalui perkembangan karakter individu seseorang. Karena manusia hidup dalam lingkungan sosial dan budaya tertentu, maka perkembangan karakter individu seseorang hanya dapat dilakukan dalam lingkungan sosial dan budaya yang bersangkutan. Artinya, perkembangan karakter dapat dilakukan dalam suatu proses pendidikan yang tidak melepaskan peserta didik dari lingkungan sosial, masyarakat, dan budaya bangsa.

Hal ini menjadi menarik untuk diteliti bagaimana jenis tindak tutur, fungsi komunikasi tuturan, dan nilai karakter yang terdapat dalam tari gambuh disampaikan dalam sebuah penelitian yang berjudul "Tindak Tutur, Fungsi Komunikasi Tuturan, dan Nilai Karakter pada Seni Tari Gambuh Sesuai dengan 18 Nilai Karakter Kurikulum 2013"

\section{Metode Penelitian}

Penelitian ini merupakan penelitian kualitatif. Instrumen utama dalam penelitian ini adalah peneliti sendiri. Sebagai human instrument peneliti harus menetapkan fokus penelitian, memilih informan sebagai sumber data, mengumpulkan data, menilai kualitas data, melakukan analisis data, menafsirkan data, dan membuat simpulan atas temuan yang diperoleh.

Selain peneliti yang merupakan instrumen utama dalam penelitian ini, ketika fokus penelitian sudah mulai jelas, peneliti juga menggunakan korpus data sebagai instrumen tambahan yang digunakan dalam proses pengumpulan data untuk mencatat baik hasil observasi maupun rekaman pada saat proses pengumpulan data.

\section{- Teori}

Untuk membedah masalah dalam penelitian, peneliti menggunakan teori tindak tutur yang terdiri atas lokusi, ilokusi, dan perlokusi. Peneliti 
juga menggunakan fungsi komunikasi menurut Searle yang terdapat pada teori tindak tutur ilokusi.

\section{Pembahasan}

Pada bab IV ini dipaparkan hasil penelitian yang telah dilakukan pada pementasan tari gambuh yang berjudul "Swayamwara" di Desa Bungkulan Kabupaten Buleleng. Pemaparan pada bab ini mengacu pada rumusan masalah yang telah ditetapkan.

Bentuk pembahasan pada bab ini meliputi kajian tentang jenis-jenis percakapan pada tari gambuh dengan melihat makna kalimat melalui kacamata pragmatik, yaitu lokusi, ilokusi, dan perlokusi. Selanjutnya dibahas mengenai makna ilokusi secara spesifik menurut fungsi komunikatif. Terakhir, dibahas nilai-nilai karakter yang terdapat pada pementasan tari gambuh yang selanjutnya dihubungkan dengan 18 nilai karakter pada kurikulum 2013.

\section{Jenis-Jenis Tindak Tutur pada Seni Tari Gambuh yang Berjudul 'Swayamwara'}

Dalam kacamata pragmatik secara umum terdapat tiga jenis kelompok tindak tutur yang terdiri atas lokusi, ilokusi, dan perlokusi. Setelah dilakukan analisis pada percakapan tari gambuh yang berjudul "Swayamwara" di Desa Bungkulan Kabupaten Buleleng ditemukan data sebagai berikut.

\subsection{Lokusi}

Makna lokusi yang dipaparkan pada bagian ini berasal dari percakapan Galuh (tuan putri) dengan Condong (pelayan tuan putri). Pada penggalan percakapan di bawah ini, Galuh mengucapkan bahasa Kawi yang diartikan ke dalam bahasa Bali oleh Condong.

\section{(1) Galuh : Sinelagin mirah kresnadana \\ Condong : Semalih keselag-selagin gelung prabu cokor idewa antuk mirah kresna dana. \\ 'Mahkota tuanku dipenuhi oleh mirah Kresnadana'}

(2) Galuh : Masekar sumenasa pita

Condong : Inggih masekar gelung prabu palungguh cokor idewa antuk sekar cempaka putih.

'Baik, mahkota tuanku juga berisi bunga cempaka putih'

\section{Galuh : Nanging erek ikaang manawa ratna \\ Condong : Inggih semalih bek (akeh) medaging sasocan sane mule-mule \\ 'Baik, juga banyak berisi permata yang klasik'}

Pada penggalan percakapan data (1), ditemukan bahwa penutur (Galuh) bermaksud untuk menyatakan bahwa mahkotanya dikelilingi emas atau terbuat dari emas. Kalimat di atas tidak memiliki tendensi lain apalagi memerintah. Kalimat tersebut murni hanya memberikan informasi.

Pada penggalan percakapan data (2) juga terkandung makna lokusi, yaitu maksud dari kalimat ini hanya menginformasikan saja. Penutur (Galuh) bermaksud memberitahukan pada lawan tutur (Condong) bahwa mahkotanya dipenuhi mirah yang bernama Kresnadana. Sama seperti kalimat sebelumnya kalimat ini juga tidak memiliki tendensi di dalamnya.

Pada data (3) penutur (Galuh) bermaksud untuk memberikan informasi. Makna kalimat di atas adalah bahwa mahkotanya juga berisi bunga cempaka putih. Kalimat tersebut tentu bermakna lokusi melihat tidak adanya tendensi lain di dalamnya.

Total terdapat 17 data yang dapat dikategorikan ke dalam jenis tindak tutur lokusi.

\subsection{Ilokusi}

(4) Galuh : Pantes ingsun manyaluk gelung 'Pantaskah aku menggunakan mahkota'

Condong : Pangus pisan wiyakti ritatkala cokor idewa, titiang 
memantesang.

'Cocok sekali

tuanku menggunakan

mahkota'

Galuh : Kadi jelada anemu riris
'Seperti mendung yang
membawa hujan'
Condong : Inggih yen indargamayang
kawentenan rambut cokor idewa
sekadi guleme sane
mangemu sabeh
'Baiklah apabila
diumpamakan rambut
tuanku layaknya seperti
mendung yang membawa
hujan, berwarna hitam pekat'

Berdasarkan data (4), dapat diartikan bahwa lawan tutur (Condong) bermaksud memberikan pujian terhadap mahkota yang digunakan penutur (Galuh) dengan mengatakan bahwa Galuh cocok sekali menggunakan mahkota tersebut. Makna pujian yang terdapat pada kalimat tersebut merupakan sebuah tendensi yang disampaikan lawan tutur sehingga kalimat tersebut tergolong kalimat ilokusi.

Pada penggalan percakapan data (5) dapat ditemukan makna kalimat seperti data sebelumnya, yaitu kalimat memiliki makna ilokusi. Penutur pada kalimat di atas membanggakan warna rambut yang dimilikin's yang diumpakan seperti warna mendung ya ? membawa hujan, hitam gelap pekat. Pada kalimat kedua yang diutarakan oleh lawan tutur, ditemukan pula tendensi yang bersifat memuji dengan membenarkan kalimat yang diutarakan oleh penutur. Dengan demikian, disimpulkan bahwa kalimat di atas memiliki makna ilokusi.

Total terdapat dua puluh data yang dapat dikategorikan ke dalam jenis tindak tutur ilokusi.

\subsection{Perlokusi}

Dalam Percakapan pementasan tari gambuh Desa Bungkulan Kabupaten Buleleng, ditemukan dua buah kalimat yang memiliki perlokusi, salah satu di antaranya sebagai berikut. penasar : Jani ida ngelarang ane madan Swayamwara. Sapa sira ja ane nyidayang ngematiang I Wanaru ento pacang mejenengan agung dini di Jenggala Pura tur nganggen raris Ida Dewa Agung Istri permaisuri

'Sekarang beliau menggelar yang namanya sayembara.

Siapa saja yang

bisa membunuh I Wanaru dia akan diangkat menjadi raja di Jenggala Pura dan menjadikan Ida Dewa Agung Istri sebagai permaisuri'

Kartala : Di suba lantas ngematiang $I$ Wanaru, dini lantas dadiange raja tur ngangge Ida

Dewa Agung Istri permaisuri, Bli

'Setelah membunuh I Wanaru, lalu di sini dijadikan raja dan dijadikan Ida Dewa

Agung Istri sebagai permaisuri, Kak?'

Penasar : To jani ane ngeranayang panjake ade ane ngalih sabuk tur ade masi ane ngelah pekakas kanti ngadep uma

'Itu sekarang yang membuat rakyat ada yang mencari

kekebalan dan ada juga yang memiliki barang dengan ilmu hitam sampai menjual sawah'

Berdasarkan data (6), dapat dilihat penggalan kalimat pertama yang menyatakan bahwa 'Sekarang beliau menggelar yang namanya sayembara. Siapa saja yang bisa membunuh I Wanaru dia akan diangkat menjadi raja di Jenggala Pura dan menjadikan Ida Dewa Agung Istri sebagai permaisuri'. Orang yang mendengar pernyataan tersebut, tentunya akan berusaha untuk ikut dalam sayembara demi mendapatkan takhta dan permaisuri. Hal ini dapat dibuktikan dengan pernyataan lanjutan penasar sebagai 
berikut 'Itu sekarang yang membuat rakyat ada yang mencari kekebalan dan ada juga yang memiliki barang dengan ilmu hitam sampai menjual sawah'. Hal ini secara tidak langsung membuktikan bahwa benar masyarakat dalam cerita tersebut sangat antusias dalam menanggapi informasi tersebut. Dengan demikian, dapat dikatakan bahwa telah ditemukan makna perlokusi pada penggalan percakapan di atas.

\section{Fungsi Komunikasi pada Seni Tari Gambuh yang Berjudul "Swayamwara" \\ Searle \\ (1968:47--48), telah} mengelompokkan tindak ilokusi yang menunjukkan fungsi komunikatif ke dalam lima kategori. Lima kategori tindak ilokusi yang menunjukkan fungsi komunikatif, yaitu fungsi asertif, fungsi direktif, fungsi komisif, fungsi ekspresif, dan fungsi deklaratif.

Berikut fungsi-fungsi komunikatif menurut Searle yang ditemukan dalam percakapan pementasan pada tari gambuh yang berjudul "Swayamwara" di Desa Bungkulan, Kabupaten Buleleng.

\subsection{Fungsi Asertif}

Tindak ilokusi asertif ini melibatkan pembicara pada kebenaran proposisi yang diekspresikan. Adapun beberapa fungsi tuturan asertif yang terkandung dalam tuturan penutur, terhadap mitra tuturnya dapat berfungsi untuk menyatakan, memberitahukan, menyarankan, membanggakan, mengeluh, menuntut, dan melaporkan. Berikut salah satu fungsi asertif yang ditemukan pada penggalan percakapan tari gambuh yang berjudul "Swayemwara".

\section{(7) Penasar: Duaning ida meraga dana, Bakti ring panjak ento ane ngeranaang liang. Ida naler ngelarang sane mewasta dharma 'Karena beliau berkepribadian dermawan, memperhatikan rakyat itu yang membuat bahagia, dan beliau juga menjalankan kebajikan'}

Pada penggalan percakapan data (7), penutur (penasar) mengutarakan tuturan yang memiliki makna ilokusi asertif. Penutur (penasar) mengatakan bahwa dirinya merasa bahagia karena kebaikan yang dilakukan oleh sang raja. Dalam konteks kalimat ini terkandung tendensi yang bersifat membanggakan di dalamnya. Penutur membanggakan sang raja sebagai bentuk nilai kebanggaan yang diutarakannya terhadap lawan tutur. Dengan adanya tendensi tersebut kalimat ini dapat dikatakan memiliki makna ilokusi asertif.

\subsection{Fungsi Direktif}

Tindak ilokusi direktif ini dimaksudkan untuk menimbulkan beberapa efek melalui tindakan sang penyimak. Adapun beberapa fungsi tuturan direktif yang terkandung dalam tuturan penutur terhadap mitra tuturnya dapat berfungsi untuk memesan, memerintahkan, memohon, meminta, menyarankan, menganjurkan, dan menasihati. Berikut salah satu fungsi direktif yang ditemukan pada percakapan tari gambuh yang berjudul "Swayemwara" di Desa Bungkulan, Kabupaten Buleleng;

$$
\begin{aligned}
\text { Kartala: Di Bali nak mule pulau dewata, } \\
\text { pulau wisata. Nak mule } \\
\text { patut irage ngelestariang seni- } \\
\text { seni tradisional } \\
\text { 'Di Bali memang Pulau Dewata, } \\
\\
\text { Pulau Wisata. Sudah } \\
\text { seharusnya kita } \\
\text { melestarikan seni-seni } \\
\text { tradisional' }
\end{aligned}
$$

Pada penggalan percakapan data (8), peneliti menemukan adanya tindak tutur ilokusi direktif. Kartala pada kalimat pertama menuturkan Bali yang menjadi pulau wisata sehingga merupakan kewajiban untuk masyarakat Bali menjaga kesenian tradisional. Makna pada kalimat pertama tersebut merupakan suatu kalimat yang memiliki tendensi meminta kepada setiap masyarakat Bali untuk menjaga dan melestarikan seni budaya Bali. Dengan demikian, kalimat pertama yang diucapkan Kartala merupakan tindak tutur ilokusi direktif. 


\subsection{Fungsi Komisif}

Tindak ilokusi komisif ini melibatkan pembicara pada beberapa tindakan yang akan datang. Adapun beberapa fungsi tuturan komisif yang terkandung dalam tuturan penutur terhadap mitra tuturnya dapat berfungsi untuk menjanjikan, bersumpah, menawarkan, dan memanjatkan (doa). Berikut salah satu fungsi komisif yang ditemukan pada percakapan tari gambuh yang berjudul "Swayemwara" di Desa Bungkulan, Kabupaten Buleleng.

(9) Mahapatih : Inggih yan tuhu mangkane kaya saturan sira sang prabu, titiang makarue bipraya mabela pati angasor akna sirang kala wanaru 'Baiklah apabila demikian keinginan sang Prabu, Kami berdua akan berani bertaruh nyawa melawan si raksasa'

Pada penggalan percakapan data (9), mahapatih menyatakan kesanggupannya untuk bertaruh nyawa melawan si raksasa. Pernyataan mahapatih di sini memiliki tendensi berjanji dan bersumpah dilihat dari kata bertaruh nyawa yang disampaikan. Oleh karena itu, pernyataan mahapatih juga dapat dikatakan memiliki makna ilokusi komisif.

\subsection{Fungsi Ekspresif}

Tindak ilokusi ekspresif ini mempunyai fungsi untuk mengekspresikan, mengungkapkan, atau memberitahukan sikap psikologis sang pembicara menuju suatu pernyataan keadaan yang diperkirakan oleh ilokusi. Adapun beberapa fungsi tuturan ekspresif yang terkandung di dalam tuturan penutur terhadap mitra tutur dapat berfungsi untuk mengucapkan terima kasih, mengucapkan selamat, memaafkan, mengampuni, menyalahkan, memuji, menyatakan belasungkawa, dan sebagainya. Berikut salah satu fungsi ekspresif yang ditemukan pada percakapan tari gambuh yang berjudul "Swayemwara" di Desa Bungkulan, Kabupaten Buleleng.
Kartala : Ae, pang sing nyan punah seni budaya baline. Ne care

irage jani contohne bli. Ipidan nak sing ade

bajang-bajang ane ajak icang ngigel, ne jani sube madan ngenah generasi muda memajukan kesenian bali. 'Iya, agar tidak punah seni budaya Bali. Seperti kita sekarang contohnya Kak. Dahulu tidak ada muda-muda yang aku ajak menari, sekarang sudah terlihat generasi muda memajukan kesenian Bali'

Pada penggalan percakapan data (10) yang diucapkan oleh Kartala, di sana terdapat tindak tutur yang memiliki makna ilokusi ekspresif. Hal tersebut dapat dilihat dari pernyataan yang mengatakan bahwa "Dahulu tidak ada mudamuda yang aku ajak menari, sekarang sudah terlihat generasi muda memajukan kesenian Bali". pada kalimat ini Kartala tidak hanya sekedar menyampaikan informasi, tetapi juga memuji dan membanggakan para generasi muda yang sudah mau menjaga dan melestarikan kesenian-kesenian tradisional. Oleh karena itu, kalimat ketiga pada penggalan percakapan di atas dapat dikatakan memiliki makna ilokusi ekspresif.

\subsection{Fungsi Deklaratif}

Tindak ilokusi deklaratif ini adalah ilokusi yang bila performasinya berhasil, akan menyebabkan korespondensi yang baik antara proposisional dan realitas. Adapun beberapa fungsi tuturan deklaratif yang terkandung dalam tuturan penutur terhadap mitra tutur dapat berfungsi untuk menyerahkan diri, memecat, membebaskan, membaptis, memberi nama, mengucilkan, menunjuk, menentukan, menjatuhkan hukuman, memvonis dan sebagainya. Berikut salah satu fungsi deklaratif yang ditemukan pada percakapan tari gambuh yang berjudul "Swayemwara" di Desa Bungkulan, Kabupaten Buleleng. 
(11) Ida Dewa Agung: Ingulun bipraya angelaraken

Swayamwara., manira ane dwi Mangke akna ikanang mahapatihku

'Aku akan menggelar sayembara. Sekarang aku memiliki dua mahapatih. Suruh mereka menghadap padaku'

Pada penggalan percakapan data (11), dapat ditemukan kalimat yang mengandung makna tindak tutur ilokusi deklaratif yang bersifat memutuskan. Pada kalimat tersebut, Sang Raja mengungkapkan bahwa beliau akan menggelar suatu sayembara, yang berarti beliau telah mengambil kepetusan untuk menggelar sebuah sayembara untuk menyelamatkan sang putri. Dengan demikian dapat dikatakan bahwa kalimat di atas memiliki makna tindak tutur yang bermakna ilokusi deklaratif.

\section{Hubungan Nilai-Nilai Karakter yang Terdapat pada Pementasan Seni Tari Gambuh dengan 18 Nilai Karakter pada Kurikulum 2013}

Seperti diketahui bahwa menurut Kemendiknas, karakter adalah sebagai nilai-nilai yang khas baik (tahu nilai kebaikan, mau berbuat baik, nyata berkehidupan baik, dan berdampak baik terhadap lingkungan) yang terpatri dalam diri dan terejawantahkan dalam perilaku (Kebijakan Nasional Pembangunan Karakter Bangsa, 2010). Pendidikan karakter ini biasanya diajarkan dalam ranah pendidikan formal layaknya sekolah dan perguruan tinggi. Namun, tidak menutup kemungkinan bahwa sebuah nilai karakter telah diajarkan melalui seni dan budaya sejak zaman dahulu. Dalam sebuah pementasan tradisional, selain gerak tari dan tindak tutur terdapat pula berbagai nilai-nilai karakter yang terkandung di dalam pementasan tersebut. Hal ini menjadi salah satu ranah pendidikan nonformal bagi masyarakat umum untuk mengenal berbagai nilai karakter dalam kehidupan sehari-hari.

Adapun nilai-nilai karakter yang ditemukan dalam pementasan seni tari gambuh yang berjudul "Swayamwara" di Desa Bungkulan, Kabupaten Buleleng meliputi religius, toleransi, disiplin, kerja keras, demokratis, rasa ingin tahu, semangat kebangsaan, cinta tanah air, menghargai prestasi, bersahabat, peduli sosial, tanggung jawab, dan berani.

\section{Simpulan}

Berdasarkan hasil penelitian yang telah dilakukan, didapatkan simpulan sebagai berikut.

1. Berdasarkan hasil penelitian yang telah dilakukan pada percakapan tari gambuh di Desa Bungkulan, Kabupaten Buleleng terdapat total temuan berupa 39 data penggalan kalimat percakapan yang mengandung 20 penggalan percakapan yang mengandung makna ilokusi, terdapat 17 penggalan percakapan yang mengandung makna lokusi, dan terdapat 2 penggalan percakapan yang mengandung makna perlokusi. Dalam ulasan percakapan pada tari gambuh tersebut adapun bahasa yang digunakan meliputi bahasa Kawi dan juga bahasa Bali. Bahasa Kawi digunakan atau diucapkan oleh tokoh-tokoh utama, seperti Galuh, Panji, Mahapatih, dan Raja. Bahasa Bali digunakan oleh tokoh-tokoh pendukung meliputi Penasar, Kartala, Condong, dan Semar.

2. Kalimat-kalimat percakapan pada pementasan seni tari gambuh yang berjudul "Swayamwara" mempunyai lima unsur fungsi komunikatif yang ditemukan, yaitu 11 penggalan percakapan dengan tindak tutur fungsi asertif, 5 tindak tutur fungsi direktif, 2 tindak tutur fungsi komisif, 15 tindak tutur fungsi ekspresif, dan 1 penggalan percakapan tindak tutur fungsi deklaratif. Hal ini menandakan bahwa jenis percakapan ilokusi yang terdapat pada tari gambuh tidak monoton, tetapi bersifat variatif dan komunikatif.

Percakapan-percakapan yang terdapat pada pementasan tari gambuh dengan judul "Swayamwara" tersebut juga kaya akan nilai- 
nilai kemanusiaan yang sesungguhnya mencerminkan pendidikan karakter bagi para penonton. Adapun nilai-nilai karakter yang muncul pada pementasan tersebut meliputi 12 nilai karakter dari 18 nilai karakter kurikulum 2013 pada pementasan seni tari gambuh yang berjudul "Swayamwara", yakni nilai religius, nilai toleransi, nilai disiplin, nilai kerja keras, nilai demokrasi, nilai rasa ingin tahu, nilai semangat kebangsaan, nilai cinta tanah Air, nilai menghargai prestasi, nilai bersahabat, nilai peduli sosial, dan nilai tanggung jawab. Dari 18 nilai karakter kurikulum 2013, terdapat 6 nilai yang tidak ditemukan pada pementasan seni tari gambuh yang berjudul "Swayamwara", yakni nilai jujur, nilai kreatif, nilai mandiri, nilai cinta damai, nilai gemar membaca, dan nilai peduli lingkungan. Di sisi lain, ditemukan satu nilai yang tidak terdapat pada 18 karakter kurikulum 2013, yakni nilai berani.

\section{Daftar Pustaka}

Andrianto, Tuhana Tufiq. 2011. Mengembangkan Karakter Sukses Anak di Era Cyber. Yogyakarta: Ar-Ruzz Media.

Anwari. 2017. "Tindak Tutur dalam Upacara Pernikahan Masyarakat Madura di Desa Kalidandan, Pakuniran, Probolinggo: Kajian Pragmatik." Linguistika: Buletin Ilmiah Program Magister Linguistik Universitas Udayana.

https://ojs. unud. ac. id/index.php/

linguistika/article/view/48034

Bungin, Burhan. 2003. Analisis Data Penelitian Kualitatif(Pemahaman Filosofis dan Metodologis ke Arah Penguasaan Model Aplikasi. Jakarta: PT Raja Grafindo Persada.

Chaer, Abdul dan Leonie Agustina. 2004. Sosiolinguistik. Jakarta: Rineka Cipta.

Dina, Fenda Puspita Sari. 2012. "Tindak Tutur dan Fungsi Tuturan Ekspresif dalam Acara Galau Nite di Metro Tv:
Suatu Kajian Pragmatik.” Surabaya: Universitas Negeri Surabaya

Jiwana, Gandara. 2012. Tari Gambuh. Diunduh dari:

http://gandarajiwana.blogspot.co.id/2012/ 11/normal-0-false-false-false-in-X-none $\underline{x . h t m l}$

John R, Searle. 1969. Speech Acts: An essay In The Philosophy of Language. Cambridge University Press.

Keraf, Gorys. 1997. Komposisi: Sebuah Pengantar Kemahiran Bahasa. Ende-Flores: Nusa Indah.

Kridalaksana, Harimurti. 1985. Tata bahasa Deskriptif Bahasa Indonesia: Sintaksis. Jakarta: Pusat Pembinaan dan Pengembangan Bahasa Departemen Pendidikan dan Kebudayaan.

Leech, Geoffrey. 1993. Prinsip-Prinsip Pragmatik. Jakarta: Penerbit Universitas Indonesia (UI-Press)

Levinson, S.C. 1983. Pragmatics. London: Cambridge University Press.

Mudzakir, Achmad. 2013. A speech Act Analysis of Direct Utterances on Short Strory Mr. Know All. Surakarta: Universitas Muhamadiyah

Mulyana. 2005. Kajian Wacana. Yogyakarta: Tiara Wacana.

Purwo, Bambang Kaswanti. 1990. Pragmatik dan Pengajaran Bahasa. Yogyakarta: Kanisius.

Rahardi, Kunjana. 2003. Berkenalan dengan Ilmu Bahasa Pragmatik. Malang: Dioma.

Suasti, Widjaja. 2008. Gambuh sebagai Sumber Tari dan Drama Tari di Bali.

Diunduh dari https://igeligelan.wordpress.com/2013/10/ 09/tari-gambuh/ 
Sudaryanto. 1993. Metode dan Aneka Tehnik Analisis Bahasa (Pengantar Penelitian Wahana Kebudayaan secara Linguistik). Yogyakarta: Duta Wacana University Press.

Sugiyono. 2009. Metode Penelitian Bisnis (Pendekatan Kuantitatif Kualitatif dan $R \& D)$ Bandung: Alfabeta.

Sugiyono. 2015. Metode Penelitian Pendidikan (Pendekatan Kuantitatif, Kualitatif dan $R \& D)$. Bandung: CV ALFABETA.

Sumarsono. 2007. Sosiolinguistik.Yogyakarta: Pustaka Pelajar.

Sofyan, Asep \& Bagus Susetyo. 2017. "Penanaman Nilai Karakter Melalui Pembelajaran Seni Musik di SMP Negeri 2 Semarang." Semarang: Universitas Negeri Semarang.

Tarigan, Henry Guntur. 2009. Pengajaran Semantik. Bandung: Angkasa.

Widnyana, Hendra. 2018. "Representasi Ideologi dalam Tindak Tutur Tokoh Punakawan Wayang Kulit Cenk Blonk". Linguistika: Buletin Ilmiah Program Magister Linguistik Universitas Udayana. https://ojs. unud. ac. id/index. php/ linguistika/article/view/48034

Wijana, I Dewa Putu. 2009. Analisis Wacana Pragmatik: Kajian Teori dan Analisis. Surakarta: Yuma Pustaka.

Zoetmulder, P.J. 1985. Kalangwan, Sastra Jawa Kuno Selayang pandang.

Jakarta: Djambatan.

Zuriah, Nurul. 2005. Metodologi Penelitian. Jakarta: Bumi Aksara. 